\title{
MAKNA PUJASMARA DALAM KAKAWIN HANYANG NIRARTHA
}

\author{
${ }^{1}$ Ida Ayu Istri Agung Dharmayanti, ${ }^{2}$ I Nyoman Suarka, ${ }^{3}$ Ida Bagus Rai Putra \\ Dinas Kebudayaan Kota Madya Denpasar ${ }^{1}$ \\ Fakultas Ilmu Budaya Universitas Udayana ${ }^{2,3}$ \\ e-mail: ${ }^{1}$ idaayuistriagungdharmayanti@yahoo.co.id \\ ${ }^{2}$ Email: tuarik4@yahoo.com \\ ${ }^{3}$ Email: rai_putra@unud.ac.id
}

Abstrak-Semesta dan manusia memiliki hubungan yang saling berkaitan. Jika antara bhuwana agung dan bhuwana alit tidak seimbang, akan terjadi bencana alam dan kebobrokan mental manusia. Dalam teks Kakawin Hañang Nirartha dituliskan beberapa bait metrum yang menyuratkan keindahan alam sebagai refleksi dari bhuwana agung dan keelokan wanita sebagai refleksi dari bhuwana alit. Pujasmara merupakan sebuah wacana pemujaan yang dipersembahkan kepada Bhatara Smara dan Bhatari Ratih dalam manifestasinya sebagai dewa cinta. Cinta yang dimaksud di sini tidak hanya sekadar cinta terhadap lawan jenis, tetapi juga dapat mencintai diri sendiri dan menyadari keberadaan alam semesta sebagai tempat berinteraksi dengan makhluk hidup lainnya.

Pada penelitian ini analisis difokuskan pada makna pujasmara yang bertujuan untuk mengetahui makna wacana pujasmara dalam Kakawin Hañang Nirartha. Teori yang digunakan dalam penelitian ini adalah teori semiotika Roland Barthes mengenai makna pada tataran kedua. Rancangan penelitian ini adalah dengan melakukan persiapan, tugas lapangan, dan tahap analisis. Lokasi penelitian, yaitu di Pusat Kajian Lontar Universitas Udayana. Jenis data penelitian adalah data kualitatif. Sumber data penelitian, yaitu naskah berbentuk lontar yang berada di Pusat Kajian Lontar Universitas. Instrumen penelitian ini adalah kamus sebagai alat bantu menerjemahkan teks yang berbahasa Jawa Kuno ke bahasa sasaran. Metode dan teknik pengumpulan data menggunakan studi kepustakaan. Metode dan teknik analisis data menggunakan metode kualitatif dengan teknik deskriptif analitik. Metode dan teknik penyajian hasil analisis data menggunakan metode formal dan informal.

Hasil penelitian terhadap makna Pujasmara, yakni cinta kasih dan cara untuk mengendalikan pikiran, pernapasan (pranayama) menuju kesadaran tertinggi. Ketika sudah mampu menyadari siapa dirinya, berserah diri, dan mulai memusatkan pikiran pada satu tujuan (moksa) barulah manusia dapat menunggal dengan Hyang Pencipta.

Kata Kunci: Pujasmara, Pranayama, dan Moksa 


\section{PENDAHULUAN}

Menurut pandangan agama Hindu, alam semesta yang mahaluas ini disebut bhuwana agung, sedangkan manusia disebut bhuwana alit. Tuhan menjadi sumber awal, tengah, dan akhir dari kedua alam tersebut. Alam dan isinya ini akan selalu berhubungan, saling ketergantungan, dan merupakan suatu ekosistem. Dalam hal ini diperlukan kebajikan manusia agar mampu mempertahankan keharmonisan bhuwana agung dengan bhuwana alit. Mikrokosmos bentuk analog dari makrokosmos, segala yang ada dalam makrokosmos juga yang terdapat dalam mikrokosmos. Tubuh adalah mikrokosmos, sedangkan semesta adalah makrokosmos (Dwijayanti, 2010:1). Jika bhuwana agung (makrokosmos) tidak seimbang, akan terjadi bencana alam. Begitu pula jika bhuwana alit (mikrokosmos) tidak seimbang, akan terjadi pula kemerosotan mental, tindakan asusila, dan sebagainya. Dengan demikian, upaya menyeimbangkan pikiran, perkataan, dan perbuatannya (tri kaya parisudha) sangat penting dilakukan pada zaman ini.

Pujasmara merupakan sebuah wacana yang memiliki makna sebagai pemujaan. Simbol pemujaan kepada alam semesta yang banyak diungkapkan dalam teks Kakawin Hañang Nirartha mengisyaratkan bahwa pujasmara itu tak hanya dipersembahkan kepada Bhatara Smara dan Bhatari Ratih, tetapi juga kepada alam semesta yang menghubungkan antara bhuwana agung serta bhuwana alit. Dalam teks Kakawin Hañang Nirartha dipaparkan mengenai keindahan dan estetika alam semesta yang sangat erat kaitannya dengan pelestarian lingkungan serta keharmonisan yang dalam konsep Hindu di Bali dikenal dengan tri hita karana. Konsep tersebut membahas cara menjaga hubungan baik manusia dengan Tuhan (parhyangan), hubungan baik manusia dengan manusia (pawongan), dan hubungan baik manusia dengan alam sekitar (palemahan). Tri hita karana merupakan filosofi hidup yang menjadi bagian dari hidup manusia. Ketika sikap hidup dibentuk karena pola pikir menerapkan tri hita karana, di situlah keharmonisan akan selalu terjaga. Isi teks Kakawin Hañang Nirartha memaparkan serta merefleksikan cara seorang kawi memuja semesta beserta keindahannya. Dalam Kakawin Hañang Nirartha setiap teks mengisyaratkan bahwa pikiran merupakan pusat segalanya. Para kawi wiku dikenal sebagai penganut yoga yang mencari sang dewa lewat sarana-sarana yang menghadirkan seorang dewa (Agastia, 2010:26--27). Yoga sastra merupakan jalan yang dipilih pengarang teks kakawin untuk menemukan jalan mencapai kamoksan (menyatu dengan Tuhan).

Teks Kakawin Hañang Nirartha memberikan gambaran pemujaan kepada kebesaran Tuhan melalui keindahan alam seperti gunung dan lautan. Karya sastra ini merupakan sumber ajaran yoga sastra karena mengandung prinsip-prinsip, proses kreatif, dan imajinatif seorang pengarang. Ajaran yoga sastra dalam Kakawin Hañang Nirartha merupakan ajaran yoga sastra yang diambil dari samara puja, memuja dengan cinta dan hubungan cinta kasih sehingga menghasilkan kakawin. Agastia (2011:1) menegaskan bahwa yoga sastra merupakan jalan yang dipilih oleh pangawi untuk memuja kebesaran Pencipta. Menurut Agastia, yoga sastra adalah cara memuja dengan mensthana-kan dewa yang dipuja dan memusatkan pikiran kepada-Nya.

Cinta kasih dalam pengertiannya merupakan kasih sayang yang diberikan hanya kepada sesama makhluk hidup. Namun dalam karya sastra Kakawin Hañang Nirartha disuratkan bahwa cinta kasih tak hanya ditujukan kepada lawan jenis, tetapi juga cinta terhadap alam semesta. Menurut 
Kamus Besar Bahasa Indonesia (2005:390) Harmonisasi mengandung pengertian pengharmonisan; upaya mencari keselarasan, sedangkan alam berarti segala yang ada di langit dan di bumi (seperti bumi, bintang, dan kekuatan). Alam merupakan tempat makhluk hidup melangsungkan kehidupannya. Makhluk hidup dan alam menjadi dua unsur yang saling membutuhkan. Alam memberikan apa yang dibutuhkan makhluk hidup dan makhluk hidup pun berkewajiban menjaga alam tersebut agar tidak rusak sehingga terciptalah hubungan harmonis antara makhluk hidup dan alam. Pemujaan tidak semata dianggap sebagai penghormatan atau tempat memuja kepada dewa-dewa. Dalam perkembangannya kemudian pujaan ditujukan kepada orang yang dicintai, pahlawan, dan Tuhan Yang Maha Esa. Pemujaan kepada Tuhan adalah perwujudan cinta manusia kepada Tuhan karena merupakan inti, nilai dan makna dari kehidupan yang sebenarnya. Cara pemujaan dalam kehidupan manusia menunjukkan berbagai perbedaan sesuai dengan ajaran agama, kepercayaan, kondisi, dan situasi. Tempat pemujaan merupakan tempat komunikasi manusia dengan Tuhan.

Setiap karya sastra memiliki kekhasan. Kekhasan Kakawin Hañang Nirartha ditunjukkan oleh (1) substansi sastra tutur, yang mengandung pemahaman teoretis dan nilai-nilai filosofis mengenai ajaran agama Hindu di Bali, yang merujuk pada hal-hal yang bersifat empiris dan (2) ajaran pujasmara diwacanakan dalam karya sastra ini. Selain hal tersebut, teks Kakawin Hañang Nirartha sebelumnya sudah pernah diteliti, tetapi hanya sebatas struktur formal dan gaya bahasanya. Oleh karena itu, perlu dilakukan penelitian lebih lanjut mengenai makna yang terkandung dalam teks tersebut. Berdasarkan hal itu, Kakawin Hañang Nirartha layak untuk diteliti. Penggalian makna mengenai pujasmara yang diwacanakan dalam karya sastra ini menjadi permasalahan utama dalam penelitian ini

Ada beberapa penelitian yang memiliki relevansi dengan penelitian ini. Pertama, penelitian Palguna (Dharma Sunya: Memuja dan Meneliti Siwa) diterbitkan oleh Yayasan Dharma Sastra tahun 1999 merupakan jembatan penghubung pada penelitian terhadap pemujaan. Dharma Sunya yang ditelitinya menitikberatkan pada gagasan-gagasan kesunyatan, kenirmalan, keheningan yang mampu melahirkan segalanya termasuk karya sastra. Tentunya pemikiran I.B.M. Dharma Palguna juga menjadi acuan, pembanding, dan pemutar dalam penelitian wacana pemujaan dalam Kakawin Hañang Nirartha.

Kedua, penelitian Dwijayanti (2010) menguraikan panjang lebar mengenai yoga sastra yang berkaitan dengan ajaran kemanunggalan dan kalepasan. Konsepkonsep ajaran kalepasan difokuskan pada penelitian yang berupa tesis dengan judul "Kalepasan dalam Kakawin Panca Dharma". Tulisan Dwijayanti ini banyak membahas kemanunggalan atau kalepasan. Disamping itu, juga mengarah pada penyadaran seorang pengawi terhadap penulisan karya sastranya melalui yoga sastra. Dengan demikian, dalam hal ini digunakan sebagai acuan sekaligus membandingkan dengan teks Kakawin Hanyang Nirartha yang di dalamnya terkandung banyak ajaran-ajaran yoga sastra. 


\section{LANDASAN TEORI}

Makna wacana pujasmara dalam Kakawin Hañang Nirartha ini dibedah dengan teori semiotik Roland Barthes (Cobley dan Janz dalam Ratna, 2009:97). Barthes secara panjang lebar mengulas apa yang sering disebut sebagai sistem pemaknaan tataran kedua, yang dibangun di atas sistem lain yang telah ada sebelumnya. Sastra merupakan contoh paling jelas sistem pemaknaan tataran kedua yang dibangun di atas bahasa sebagai sistem yang pertama. Sistem kedua ini oleh Barthes disebut dengan konotatif, yang di dalam Mythologies secara tegas dibedakan dari denotatif atau sistem pemaknaan tataran pertama (Kaelan, 2009:204).

Dalam konsep Barthes, tanda konotatif tidak sekadar memiliki makna tambahan, tetapi juga mengandung kedua bagian tanda denotatif yang melandasi keberadaannya. Pada dasarnya ada perbedaan antara denotasi dan konotasi yang dimengerti oleh Barthes. Dalam pengertian umum, denotasi biasanya dimengerti sebagai makna harfiah, makna yang "sesungguhnya", bahkan kadang kala juga dirancukan dengan referensi atau acuan. Proses signifikasi yang secara tradisional disebut sebagai denotasi ini biasanya mengacu kepada penggunaan bahasa dengan arti yang sesuai dengan apa yang terucap. Akan tetapi, dalam semiologi Roland Barthes dan para pengikutnya, dinyatakan bahwa denotasi merupakan sistem signifikasi tingkat pertama, sementara konotasi merupakan tingkat kedua (Kaelan, 2009:204-206).

\section{METODE PENELTIAN}

Rancangan penelitian ini adalah dengan melakukan persiapan, tugas lapangan, dan tahap analisis. Lokasi penelitian yaitu di Pusat Kajian Lontar Universitas Udayana. Jenis data penelitian adalah data kualitatif. Sumber data penelitian, yaitu naskah berbentuk lontar yang berada di Pusat Kajian Lontar Universitas. Instrumen penelitian ini adalah kamus sebagai alat bantu menerjemahkan teks yang berbahasa Jawa Kuno ke bahasa sasaran. Metode dan teknik pengumpulan data menggunakan studi kepustakaan. Metode dan teknik analisis data menggunakan metode kualitatif dengan teknik deskriptif analitik. Metode dan teknik penyajian hasil analisis data menggunakan metode formal dan informal.

\section{PEMBAHASAN}

Representasi makna pujasmara dalam teks Kakawin Hañang Nirartha dapat dijabarkan sebagai berikut.

\section{Pujasmara sebagai Ungkapan Cinta Kasih}

Kecintaan pengarang diungkapkan melalui goresan tulisan yang sesungguhnya mengungkapkan kerinduan yang amat mendalam terhadap Sang Sangkan Paraning Dumadi atau dalam hal ini, yaitu Ida Sang Hyang Widhi Wasa (Tuhan) yang bersemayam di lubuk hati yang terdalam.

Waya těki sambat ira ring kidung inaměr ahĕmbanan tatur,

Tulising wilapa rasa basa rudita kahatur sinuksmakĕn,

Ri gading nikang sumanasĕ dalëming asana pușpa susungĕn,

Mwang ikang sĕpah tinarimeng waja tuwi lumiring mareng kidung.

Terjemahan:

Lihatlah ratapannya di dalam kidung, dengan penuh kasih sayang ditulis dengan tinta emas.

Digubah dalam bentuk syair kerinduan, dengan gaya bahasa dukacita yang begitu menyentuh kalbu. 
Di gading kembang sumanasa, di dalam bunga angsana dicari.

Selain itu sepah yang diterima di gigi, terutama lirikan mata, dituangkan ke dalam nyanyian.

\section{Ungkapan pada bait Kakawin Hañang} Nirartha diatas "Waya těki sambat ira ring kidung inamĕr ahëmbanan tatur" menyebutkan bahwa cinta ditulis berupa kidung dituangkan menggunakan bahasa yang indah dan dinyanyikan dengan suara yang merdu. Dengan demikian, seorang pembaca dalam hal ini adalah Nirartha yang juga sebagai penulis mampu mencapai keheningan jiwa dan memusatkan pikiran dengan tujuan dapat menyatu dengan Sang Hyang Tunggal.

Menurut Barthes, sistem pemaknaan tataran kedua dibangun atas hal yang telah ada sebelumnya. Artinya, sebuah sistem pemaknaan tataran kedua dibangun atas bahasa sebagai sistem pertama. Seperti yang diungkapkan pada kutipan di atas "Mwang ikang sëpah tinarimeng waja tuwi lumiring mareng kidung”. Pengarang dalam hal ini Nirartha melakukan pemujaan dan mempersembahkan sesajinya tidak melalui upakara, melainkan dengan membuat goresan-goresan tulisan menjadi sebuah kata yang dijalin membentuk kalimat sehingga menjadi sebuah kidung. Kidung merupakan salah satu nyanyian yang digunakan sebagai sarana pemujaan. Melantunkan kekidungan berarti seseorang mempersembahkan rasa syukur kepada Tuhan dan rasa tulus ikhlas tanpa menggunakan sarana berupa upakara ataupun bunga (sekar).

Ada kalanya pula penyair memberikan metafora kidung dengan menggunakan kata sekar. Sekar tidak hanya berarti bunga biasa. Sekar dihubungkan dengan padma, yaitu bunga dengan delapan kelopak yang senantiasa menguasai segala arah. Sekar dikaitkan pula pada mati, bukanlah mati secara raga, tetapi mematikan rasa atau indra untuk mencapai kebahagiaan (Dwijayanti, 2010: 65). Bunga tunjung atau padma merupakan lambang kesucian atau lambang hati sanubari yang diwarisi dan diwariskan turun temurun dalam sastra kawi. Padma sama artinya dengan lotus, teratai, tunjung, dikatakan sebagai teristimewa (Zoetmulder, 1995:728). Bunga padma atau teratai sering digunakan sebagai simbol penggambaran Paramashiwa karena keistimewaan. Keistimewaan karena ia tumbuh di tiga tempat, yaitu akar bunga tumbuh di lumpur, batangnya berada di dalam air, dan bunganya yang indah tumbuh di udara. Palguna (1999:136) menggambarkan secara komprehensif bahwa bunga ini hidup di dan oleh air, tetapi tidak terkena basah. Kelopak padma yang berlapis-lapis menjadi tanda tingkat kedalaman hati yang juga berlapislapis. Kedalaman hati yang terdalam sering juga disebut "gua hati" (hrdaya guha). Sebutan yang lebih umum adalah padma hati (hrdaya padma).

Ring janmāntara ni ngulun
tëmahanangkwa tapih ing ahajöng
kinonĕngan,
Anggon rakryan amunngah ing jinĕm
arum wiru-wiru ni tepinya meh lukar,
Harsangkwahat i kungta mamrema
tëhĕr nghulun anulu-nuluh
priyambada, lĕsĕhĕng paturwan
Tibrangkun wĕdak
anguyuh panĕpi kaharas ing wët.
angĕt.

Terjemahan

Dalam penjelmaanku kelak, aku menjadi kain indah yang membangkitkan kerinduan.

Yang dipakai olehmu naik ke peraduan yang indah, lipatan-lipatan di tepinya hampir terlepas.

Hatiku rindu, tidak bisa tidur, lalu aku berupaya menyadarkan diri supaya tetap disayangi. 
Keperkasaanku pudar di tempat tidur, berupaya mencapai tepi untuk mencium bedak hangat.

Seorang bijak juga merupakan sebutan untuk seorang kawi, hanya orang bijak yang dapat menuliskan kebajikan dan ketidakbajikan secara bersama sebagai cerminan ataupun tuntunan. Swadharmma say sājjana masihin dadi (kewajiban seorang bijak adalah mengasihi sesama). Hal itu berarti bahwa setiap yang melahirkan cinta dan kasih sayang merupakan cara untuk mengobati kerinduan bertemu (menyatu) dengan Pencipta. Bakti yang tulus tanpa meninggalkan jejak di dunia adalah kekekalan seorang kawi karena hidup seorang kawi selalu mengalir dan menemukan muara lalu lebur menjadi satu dalam samudra kesunyian.

Grong sing grong pinaranku lënglèng anulis-nulis anak-anakan pudak sumar,

Ngkanĕng nusa ri dungusing karang apandan alalah asilā ngunang parung,

Ryaknyanëmbur anampuh ing watu sumong karirisan amangun kuwungkuwung,

Harsangkwi lëyĕp ing pasir pada katungkulan ulah ika yan pasang surud(KAN I bait 2).

Terjemahan

Setiap jurang kudatangi, asyik menulis di atas jantung pudak yang harum.

Di sana di sebuah pulau di atas batu karang, pohon pandan lunglai, batu menoleh jurang yang ada di bawahnya.

Ombak lautnya menyembur mengempas batu berkilauan seperti kehujanan menimbulkan bianglala.

Kecintaanku kepada keindahan laut adalah pada ombaknya yang saling mengungguli bilamana terjadi pasangsurut.
"Harsangkwi lëyĕp ing pasir pada katungkulan ulah ika yan pasang surud" kecintaan Nirartha sebagai pengarang tak hanya diungkapkan kepada pujaan hatinya, tetapi juga ditujukan kepada alam semesta (bhuwana agung) sebagai tempat pemujaan sang paramakawi. Sesungguhnya setiap ungkapan di atas menyebutkan bahwa kecintaan tersebut tak hanya diberikan terhadap pasangan. Cinta kasih umumnya diberikan kepada sesama manusia, binatang, tumbuh-tumbuhan, alam semesta dengan segala isi di dalamnya. Apabila kecintaan terhadap sesama ciptaan Tuhan diusahakan dan diupayakan secara terus-menerus dengan segala kemampuan yang dimiliki serta berpedoman pada sastra agama, keharmonisan dan kedamaian yang menjadi dambaan akan dapat diciptakan disamping itu, dengan kedamaian kebahagiaan akan dapat dirasakan.

Pujasmara merupakan bentuk representatif cinta kasih atau kasih sayang. Disamping itu, cinta merupakan pengikat yang kokoh antara manusia dan Tuhan sehingga manusia menyembah Tuhan dengan ikhlas, mengikuti perintah-Nya, dan berpegang teguh pada ajaran-Nya. Seorang pengawi dalam hal kecintaannya terhadap Tuhan tidak dengan menyembah secara langsung melalui sarana berupa upakara, namun menggunakan sarana berupa ritual dalam proses kepengarangan, yaitu menggunakan bahasa sebagai sarana pemujaan. Ungkapan-ungkapan kata membentuk kalimat dengan gaya bahasa sebagai metafora membentuk keindahan atau kalanguan.

"Ryaknyanĕmbur anampuh ing watu sumong karirisan amangun kuwungkuwung", kutipan tersebut menyebutkan bahwa ombak yang besar mengempas batu berkilau di tebing-tebing lautan, diibaratkan seperti hujan yang menimbulkan bianglala. Ungkapan di atas dapat dianalisis kembali dengan menggunakan teori semiotika Barthes yang menyatakan bahwa setiap 
bahasa memiliki sistem tanda atau pemaknaan tataran kedua. Artinya, ombak yang mengempas batu karang diibaratkan sebagai hujan yang turun dengan deras. Hujan dibentuk oleh air yang merupakan sumber kehidupan manusia. Jika tidak ada air, manusia tidak akan dapat hidup. Ombak yang mengempas batu karang atau hujan yang membasahi alam sesungguhnya memberikan refleksi kehidupan manusia. Keegoisan, keras kepala, dan sifat tamak manusia jika selalu disirami dengan dharma, ataupun kebaikan, akan memberikan keselarasan dan keharmonisan seperti bianglala yang timbul indah setelah hujan badai datang. Begitulah jika manusia mampu mengendalikan pikiran, perkataan, dan perbuatannya.

\section{Pujasmara sebagai Jalan Menuju Kalepasan}

Pujasmara merupakan pemujaan yang ditujukan kepada Bhatara Smara dan Bhatari Ratih sebagai manifestasi dari dewa keindahan. Tujuan utama pujasmara adalah pemusatan pikiran kepada para dewa, utamanya dewa keindahan beserta alam semesta (Ista Dewata).

Persoalan smara dan kelepasan dalam ajaran agama Hindu berkaitan dengan konsep catur purusa artha (empat tujuan hidup manusia), yang terdiri atas dharma, arta, kama, dan moksa. Tidak mudah menjelaskan smara. Tidak cukup hanya diterjemahkan sebagai cinta atau dewa cinta. Lebih dari itu, smara merupakan dasar dari kama (kenikmatan). Artinya, kenikmatan akan diperoleh seseorang ketika saling mencintai dan mengasihi. Cinta merupakan bentuk ikatan yang paling kuat di dalam pikiran. Ikatan menyebabkan indra tersebut selalu ingin kembali atau datang dan datang lagi. Itulah yang merupakan sebab penderitaan atma (Palguna, 1999:159). Smara atau kecintaan yang murni timbul melalui dharma. Dharma merupakan gerbang untuk masuk, tujuan, dan sarana untuk mencapai kalepasan. Artha dan kama akan datang pada orang yang menjalankan dharma. Dharma berarti, kewajiban, keadilan, kebajikan, kebaikan, agama, pekerjaan yang baik (Zoetmulder, 1995:197). Upaya memahami hakikat dan menjalankan ajaran dharma akan membantu memberikan petunjuk yang jelas mengenai tujuan hidup manusia lahir ke dunia, yaitu terlepas dari keterikatan duniawi dan bebas dari kelahiran kembali kelepasan. Konsep ini juga disebut dengan catur parama artha (empat tujuan tertinggi). Yang paling tinggi itulah disebut dengan moksa. Moksalah yang terjauh dari tempat berpijak (Palguna, 2008:67--68).

Pembebasan jiwa, menyatunya atma dengan semesta, dan hilangnya keterikatan jiwa pada tubuh adalah pengertian tentang kalepasan. Begitu banyak sebutan dan pemahaman terhadap kalepasan. Acuan pemahaman itu bergantung pada jalan mana yang dipilih oleh penekun spiritual, tingkatan yoga seseorang, dan letak titik pada tubuh saat pembebasan jiwa. Jalan pembebasan jiwa dapat dilakukan sedari dini dari hal-hal yang kecil, misalnya mengatur napas mengendalikan indra (Dwijayanti, 2010:14).

Utpati karma bayu mula winatěk dudugakěna ring agěni mandala,

Sampun purna ring angga misra wěkasan rawi těmah ika ring nabastala,

Stityangdada sasangka suda ri dalěm twas inapi dadi ratna nirmala,

Linajñana mĕngĕng ring antasamaya smarana wěkas I tungtuning mata (KAN XVII bait 9).

Terjemahan :

Utpati (kelahiran) adalah napas Ilahi dari cakra dasar ditarik naik terus menuju daerah api.

Setelah sempurna di badan, akhirnya bercampur, berubah menjadi matahari yang terang benderang. 
Sthiti (kehidupan) adalah penjelmaan rembulan di dalam hati dibayangkan menjadi permata suci.

Lina (peleburan) adalah batin yang berdengung di pusat jiwa, terus berdengung di puncak ujung penglihatan.

Semua kehidupan berawal dari kelahiran [Utpati karma bayu mula winatěk dudugakěna ring agěni mandala]. Seseorang yang bernapas dikatakan hidup. Pengolahan napas yang baik merupakan cara beryoga sederhana. Cara ini digunakan oleh wiku dalam proses kepengarangannya. Pengaturan napas dapat membuka cakracakra dalam tubuh sehingga menimbulkan api. Api [agĕni mandala] yang dimaksudkan di sini adalah manifestasi dari Dewa Brahma sebagai sumber dari kesuburan (pradana). Jika dikaitkan dengan teks Kakawin Hañang Nirartha, yang selalu mengungkapkan bahwa kerinduan Nirartha terhadap kekasihnya di sini adalah seorang wanita yang merupakan pradana. Wanita adalah sumber kesuburan dan sumber kehidupan. Pradana yang diibaratkan sebagai Dewa Brahma juga merupakan pencipta dari segala yang ada di semesta. Kerinduan Nirartha terhadap sang penciptalah yang sesungguhnya ingin diungkapkan dalam teks Kakawin Hañang Nirartha.

Tuhan dijelaskan sebagai asal dan tujuan dunia (sangkan paran, dija panangkane dumun, pacang kija pengungsine). Manusia dan seluruh ciptaan Tuhan pada akhirnya akan kembali kepadaNya. Beliau memenuhi segala yang ada di dunia. Misalnya, api di dalam kayu merupakan metafora yang sering digunakan pengarang untuk menggambarkan Tuhan sebagai kesadaran sakti dan penuh. Dalam teks Buana Kosa (2.18) jelas disebutkan bahwa (dewa) api pada kayu, tetapi tidak kelihatan karena sangat halus, itulah ibarat angkasa. Demikianlah Sang Hyang Mahadewa, ada pada semua yang berwujud, tetapi Beliau tidak tampak karena kehalusan Beliau (Tim Penyusun, 1994:19).

Setiap yang ada akan menjadi tiada dan yang tiada menjadi ada kembali [Linajñana měngěng ring antasamaya smarana wěkas I tungtuning mata]. Tahap demi tahap dilalui mulai dari merangkak, berdiri, berjalan, berlari, sampai kemudian merangkak kembali. Hal tersebut bagian dari proses. Proses kehidupan (stiti), dalam proses kehidupan manusia diibaratkan sebagai orang yang bodoh. Ketika manusia dilahirkan tidak bisa berjalan, maka ia akan belajar berjalan. Manusia tidak bisa berbicara maka ia akan belajar berbicara dan seterusnya. Artinya, dalam hidup manusia belajar untuk mengisi kebodohan tersebut. Pada teks Kakawin Hañang Nirartha di atas disebutkan bahwa [Stityangdada sasangka suda ri dalěm twas inapi dadi ratna nirmala], kehidupan adalah penjelmaan rembulan di dalam hati dibayangkan menjadi permata suci. Artinya, rembulan diibaratkan seperti kesucian Tuhan Yang Mahatunggal. Hanya hati yang bersih yang mampu merasakan keberadaan beliau sebagai maha pencipta, pemelihara, dan pelebur.

Tuhan diibaratkan seperti bayangan bulan yang berada di dalam tempayan yang berisi air. Hanya manusia yang memiliki pikiran bersih, suci, dan hening yang mampu melihat bayangan Tuhan tersebut. Tuhan akan hadir dan bersemayam di tubuh manusia manakala manusia mampu mengendalikan hawa nafsu serta memahami dirinya dengan cara melakukan yoga dan meditasi untuk memusatkan pikiran yang tertuju kepada penguasa alam semesta. Jika dikaitkan dengan isi teks Kakawin Hañang Nirartha, diungkapkan jelas bahwa jalan pengendalian diri seorang pengarang melalui yoga dan meditasi untuk menghasilkan buah karya berupa ungkapan kecintaan terhadap Dewa Keindahan dengan bahasa sebagai sarana pemujaan. Artinya, dalam proses kepengarangan tersebut Tuhan diharapkan 
hadir dan bersemayam dalam hati pengarang yang nantinya pengarang mampu menunggal dengan sang pencipta, yaitu Tuhan.

1. Mudradyatmuka mantra sari rinĕgěp katutura kita kāma satmaka, Aywadoh paraning idĕp niyata $n$ akuñcing ngaran ika siranandi ring ati,

Poh ning yoga rahasya marga hĕning ing smrĕti patitis ika granasika,

Byaktekin madanodaya karma pangarcana ri sira Bhatara Manmata.

Terjemahan :

Gerak tangan gaib dan sari-sari mantra dirapalkan menyadarkan kau akan nafsu yang menyatu.

Janganlah berpikir jauh, itulah kunci namanya, dipersatukan di dalam hati.

Perahan yoga adalah jalan rahasia, kejernihan ingatan diarahkan dengan tepat di ujung hidung.

Benarlah cinta ini bangkit melalui pemujaan kepada Bhatara Manmatha (Dewa Asmara).

2. Ndi ngwang jiwana mantuka ngwang umuwah silihasih angajĕng karasikan, Apan tan hana mati rakwa maluyeng grěha mangucapa kapriyambadan,

Netranyangdadi teja bayu matemahan wangi mawuwu sughanda nung sĕkar,

Twak mantuk ri samuhaning giri wana ksiti rudira mulih mareng nadi (KAN XXI bait 2).

Terjemahan :

Kelak jika aku hidup kembali, aku akan pulang memadu cinta kasih menikmati kenikmatan cinta.

Sebab kematian itu tidak ada, konon kembali ke rumah mengucapkan katakata cinta.

Alat penglihatannya berubah menjadi sinar. Napas berubah menjadi wangi membawa keharuman bunga.
Alat pengucap berpulang ke kumpulan gunung, hutan, tanah. Darah berpulang ke sungai.

Dua kutipan bait Kakawin Hañang Nirartha di atas menjelaskan bahwa keberadaan Tuhan sesungguhnya tidak jauh. Beliau ada dalam tubuh manusia, setiap embusan napas manusia, dan di setiap hati manusia [Aywadoh paraning iděp niyata $n$ akuñcing ngaran ika siranandi ring ati]. Dengan melakukan pranayama seseorang dapat menenangkan jiwa, memusatkan pikiran hingga mencapai kejernihan jiwa untuk melakukan pemujaan. Pemujaan kepada Dewa Asmara yang dipuja Nirartha dalam teks Kakawin Hañang Nirartha ini.

Segala yang ada di dunia tidaklah kekal adanya. Kekekalan hanya milik Tuhan. Sesungguhnya tidak ada kematian di dunia ini, yang ada hanyalah hilangnya raga dari muka bumi [Apan tan hana mati rakwa maluyeng grěha mangucapa kapriyambadan]. Jiwa dalam raga itu tetap hidup dan menyatu dengan Hyang Tunggal.

\section{SIMPULAN}

Pujasmara sebagai sebuah wacana dalam teks Kakawin Hañang Nirartha memiliki makna sebagai ungkapan cinta kasih. Cinta kasih yang tertuang dalam teks tersebut mengungkapkan bahwa cinta yang ditekankan di sini lebih kepada mencintai diri sendiri sebagai makhluk ciptaan Tuhan dan mencintai keberadaan alam semesta beserta isinya. Cinta kasih manusia dengan manusia, manusia dengan lingkungan, dan menjaga hubungan baik dengan Tuhan, akan menimbulkan keselarasan dan keharmonisan.

Selain sebagai ungkapan cinta kasih, makna pujasmara dalam teks Kakawin Hañang Nirartha juga merupakan jalan mencapai kalepasan (menunggal) dengan Tuhan (Sang Sangkan Paraning Dumadi). 
Dengan proses penyadaran, olah pernapasan, dan memusatkan pikiran pada satu tujuan, manusia akan mencapai moksa. Yoga sastra merupakan jalan yang dipilih pengarang teks kakawin untuk menemukan jalan mencapai kamoksan (menyatu dengan Tuhan).

\section{DAFTAR PUSTAKA}

Agastia, I.B.G. 2011. Anyang Nirartha (Ajaran Yoga Sastra). Denpasar:Yayasan Dharma Sastra.

Dwijayanti, Ni Made Ari. 2013. "Wacana Kalepasan dalam Kakawin Panca Dharma". Denpasar: Program Pascasarjana Unud

Halliday, M.A.K dan Hasan R. 1994. Bahasa, Konteks, dan Teks: AspekAspek Bahasa dan Pandangan Semiotik Sosial. Diterjemahkan oleh Asrudin Barori Tou dan M. Ramlan. Yogyakarta: Gadjah Mada University Press.

Kaelan, M.S. 2009. Filsafat Bahasa Semiotika dan Hermeneutika. Yogyakarta: Paradigma.

Palguna, I.B.M. Dharma. 1999. Dharma Sunya Memuja dan Meneliti Siwa. Denpasar: Yayasan Dharma Sastra.

Putra, I.B Rai. 2010. "Dharmayatra dalam Teks Dwijendra Tattwa Analisis Resepsi”. Denpasar: Disertasi Program Pascasarjana Universitas Udayana.

Ratna, Nyoman Kutha. 2009. Teori, Metode, dan Teknik Penelitian Sastra dari Strukturalisme hingga Poststrukturalisme Perspektif Wacana Sastra. Yogyakarta: Pustaka Pelajar.

Suarka, I Nyoman. 1997. "Kakawin Aji Palayon Suntingan Teks Terjemahan dan Analisis Struktur". Yogyakarta: Program Pascasarjana UGM (Tesis pada Jurusan Ilmu Humaniora).

Suhardana, K.M. 2010. CaturMarga Empat Jalan Menuju Brahman. Surabaya: Paramita.

Teeuw, A. 1988. Sastra dan Ilmu Sastra:
Pengantar Teori Sastra. Jakarta: Pustaka Jaya.

Zoetmulder, P.J. 1985. Kalangwan Sastra Jawa Kuno Selayang Pandang. Penerjemah Dick Hartoko S.J. Jakarta: Djambatan.

Zoetmulder, P.J. dan S.O. Robson. 2006. Kamus Jawa Kuno Indonesia. Penerjemah Darusuprapta dan Sumarti Suprayitna. Jakarta: Gramedia Pustaka Utama. 